\title{
Contribution to the floristic knowledge of Sillaro, Santerno, and Senio high valleys (Toscana, Italy)
}

Francesco Roma-Marzio I, , Marco D’Antraccoli 1, Fabrizio Bartolucci ${ }^{3}$, Liliana Bernardo ${ }^{4}$, Laura Cancellieri², Giuseppe Caruso $^{5}$, Fabio Conti ${ }^{3}$, David Dolci ${ }^{6}$, Giovanni Gestri ${ }^{7}$, Leonardo Gubellini ${ }^{8}$, Nicole Hofmann ${ }^{9}$, Valentina L.A. Laface ${ }^{10}$, Edda Lattanzi" ${ }^{11}$, Paolo Lavezzo ${ }^{12}$, Giovanni Maiorca ${ }^{13}$, Giulia Montepaone ${ }^{10}$, Carmelo M. Musarella ${ }^{10}$, Domenico Noto ${ }^{10}$, Enrico V. Perrino ${ }^{14}$, Elisa Proietti ${ }^{3}$, Rizzieri R. Masin ${ }^{15}$, Anna Scoppola ${ }^{2}$, Adriano Stinca ${ }^{16}$, Manuel Tiburtini ${ }^{6}$, Agnese Tilia ${ }^{17}$, Lorenzo Peruzzi ${ }^{6,}{ }^{*}$

I Sistema Museale di Ateneo, Orto e Museo Botanico, Università di Pisa, Via L. Ghini 13, 56126, Pisa, Italy 2 Dipartimento di Scienze Agrarie e Forestali, Università della Tuscia, Via San Camillo de Lellis, 01100, Viterbo, Italy 3 Centro Ricerche Floristiche dell'Appennino (Università di Camerino - Parco Nazionale del Gran Sasso e Monti della Laga), San Colombo, 67021, Barisciano (L’Aquila), Italy 4 Dipartimento di Biologia, Ecologia e Scienze della Terra (DIBEST), Università della Calabria, 87036, Arcavacata di Rende (Cosenza), Italy 5 Istituto Tecnico Agrario "Vittorio Emanuele II", Via V. Cortese 1, 88100 Catanzaro, Italy 6 Dipartimento di Biologia, Università di Pisa, Via Derna 1, 56126 Pisa, Italy 7 Via Bonfiglioli 30, 59100 Prato, Italy 8 Centro Ricerche Floristiche Marche, Provincia di Pesaro e Urbino, Via Barsanti 18, 61121 Pesaro (Pesaro e Urbino), Italy 9 Dipartimento di Scienze Agrarie, Alimentari e Ambientali, Università Politecnica delle Marche, Via Brecce Bianche 10, 60131 Ancona, Italy 10 Dipartimento di Agraria, Università Mediterranea di Reggio Calabria, Feo di Vito, 89122 Reggio Calabria, Italy I I Via V. Cerulli 59, 00143 Roma, Italy 12 Via Teodosio Macrobio 19, 00136 Roma, Italy 13 Agenzia Regionale per lo Sviluppo dell'Agricoltura Calabrese (ARSAC), Viale Trieste, 9587100 Cosenza, Italy 14 Istituto Agronomico Mediterraneo di Bari, Via Ceglie 9, 70010 Valenzano (Bari), Italy 2 I 5 Via Regazzoni Bassa 3, 35036 Montegrotto Terme (Padova), Italy 16 Dipartimento di Scienze e Tecnologie Ambientali, Biologiche e Farmaceutiche, Università della Campania Luigi Vanvitelli, Via Vivaldi 43, 81100 Caserta, Italy 17 Dipartimento di Biologia Ambientale, Sapienza Università di Roma, Piazzale A. Moro 5, 00185 Roma, Italy

Corresponding author: Marco D'Antraccoli (marco.dantraccoli@unipi.it)

Academic editor: G. Domina | Received 1 November 2020 | Accepted 1 December 2020 | Published 15 December 2020

Citation: Roma-Marzio F, D’Antraccoli M, Angeloni D, Bartolucci F, Bernardo L, Cancellieri L, Caruso G, Conti F, Dolci D, Gestri G, Gubellini L, Hofmann N, Laface VLA, Lattanzi E, Lavezzo P, Maiorca G, Montepaone G, Musarella CM, Noto D, Perrino EV, Proietti E, Masin RR, Scoppola A, Stinca A, Tiburtini M, Tilia A, Peruzzi L (2020) Contribution to the floristic knowledge of Sillaro, Santerno, and Senio high valleys (Toscana, Italy). Italian Botanist 10: 101-111. https://doi.org/10.3897/italianbotanist.10.60118

* These authors equally contributed to the paper.

Copyright Francesco Roma-Marzio et al. This is an open access article distributed under the terms of the Creative Commons Attribution License (CC BY 4.0), which permits unrestricted use, distribution, and reproduction in any medium, provided the original author and source are credited. 


\begin{abstract}
The inventory of the taxa collected during the annual field trip of the working group for Floristics, Systematics and Evolution of the Italian Botanical Society is reported. The field trip was held in 2019 along the Sillaro, Santerno, and Senio high valleys located in Toscana (central Italy). The flora documented for the studied area amounts to 492 specific and subspecific taxa (including five hybrids), belonging to 254 genera and 77 families. Bromopsis caprina, Ophrys appennina, O. classica, Polygala flavescens subsp. flavescens, and Pulmonaria vallarsae subsp. apennina were the only five Italian endemics found in the study area, whereas 28 alien taxa were detected. Finally, nine taxa (seven native and two alien) have to be considered as new records for the regional flora of Toscana.
\end{abstract}

\title{
Keywords
}

Alien species, Apennine, biodiversity, endemics, floristic novelties, vascular flora

\section{Introduction}

The working group for Floristics, Systematics and Evolution of the Italian Botanical Society has been active in increasing the floristic knowledge of poorly known areas of Italy (e.g., Bartolucci et al. 2019; Stinca et al. 2019, and literature cited therein). Territories to be investigated have been generally selected based on the low number of published floristic studies, as summarized in the map of floristic knowledge of Italy (Scoppola and Blasi 2005).

Here we present the results of the field trip held in 2019 in Toscana, selecting territories poorly known based also on the analysis of the floristic knowledge reported in the online database Wikiplantbase \#Toscana (Bedini et al. 2016; D’Antraccoli et al. 2018; Peruzzi and Bedini 2020+).

\section{Materials and methods}

\section{Study area}

Seemingly based on the work published by Zangheri (1966), the explored territory partially falls within an area reported by Scoppola and Blasi (2005) as "well known", and partially considered with a "general knowledge". However, according to the Wikiplantbase \#Toscana database (Peruzzi and Bedini 2020+), only 327 floristic records, referring to 248 taxa, were reported for this area. About $13 \%$ of these records derived from Zangheri (1966), and 50\% derived from old historical literature (Caruel 18601864; Baroni 1897-1908). Recent floristic data are available for surrounding areas, as Sasso di Castro-Monte Beni (Viciani et al. 2008, 2011, 2012; Peruzzi et al. 2009).

The study area includes the high valley of the rivers Sillaro, Santerno, and Senio, located in the province of Florence (municipalities of Firenzuola and Palazzuolo sul Senio) in the north-eastern part of Toscana, at the boundary with Emilia-Romagna (Fig. 1). The altitude ranges from $250 \mathrm{~m}$ a.s.l. at the Santerno river near Castiglioncello 


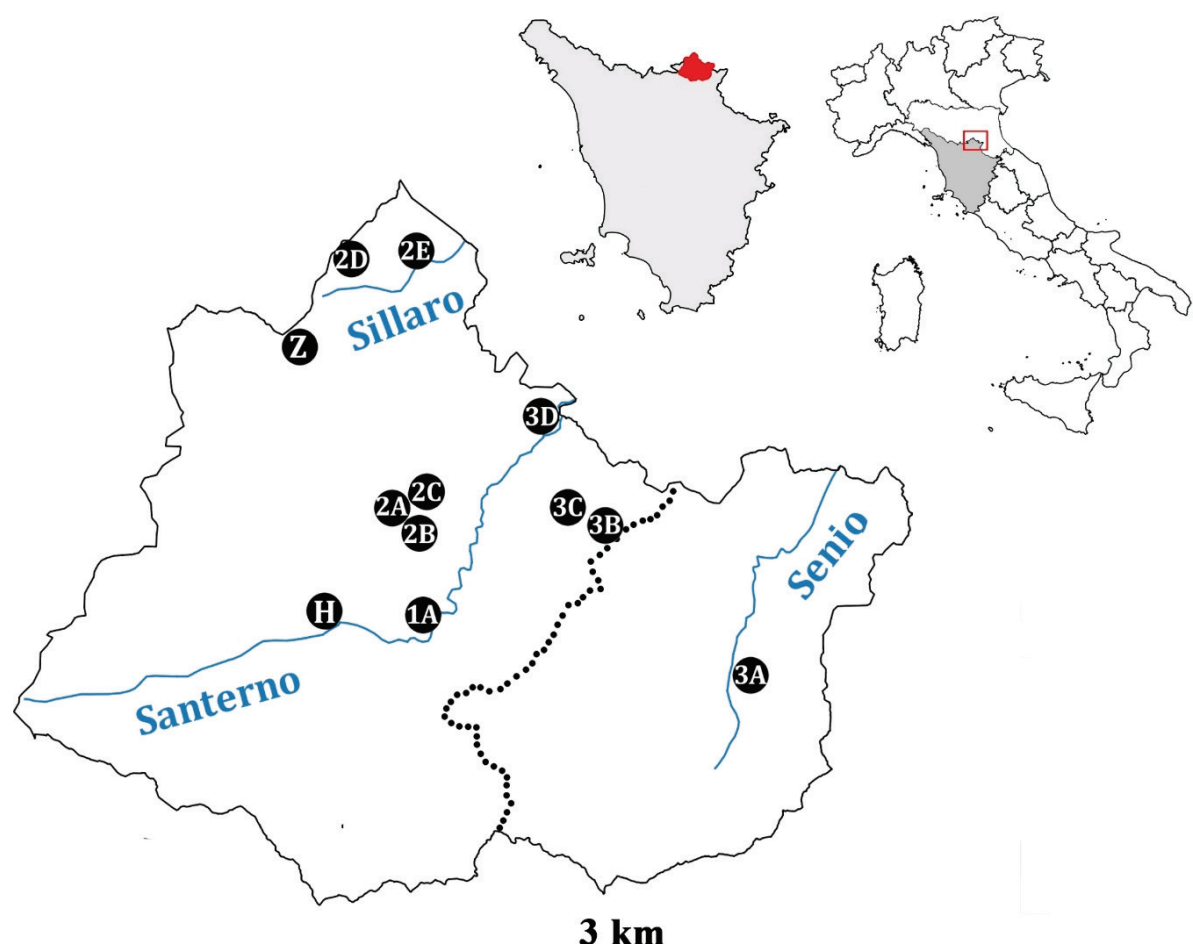

Figure I. Study area and localization of sampling sites. Dotted line represents the boundary between the municipalities of Firenzuola (westwards) and Palazzuolo sul Senio (eastwards). For details on the sample sites, see Table 1.

to $900 \mathrm{~m}$ a.s.l. at Passo del Parietaio. From the geological point of view, the study area is characterized by a marly-arenaceous and marly-limestone (turbidite) sedimentary complex of Medium Miocene, with localized outcrops of ophiolite (Regione Toscana 2019).

According to the classification of Rivas-Martinez et al. (2004) and Pesaresi et al. (2017), the study area is characterized by a temperate continental submediterranean bioclimate, belonging to the vegetation series Acero obtusati-Querco cerridis sigmetum (De Dominicis et al. 2010a, b). Indeed, the current forest vegetation is dominated by broad-leaved deciduous trees (mainly Quercus cerris L.). Other vegetation types occurring in the study area include rocky areas with therophytic communities, ophiolitic outcrops, pastures with mixed shrubs, badlands ('calanchi') and riparian zones.

\section{Sampling and identification}

In order to optimize the sampling, 12 sites were selected basing on 3 criteria: (a) to maximise the environmental heterogeneity among sampling sites, (b) to fall in the less-explored areas according to the available floristic knowledge, and (c) to ensure the sampling representativeness of all the tree valleys (Table 1 ). 


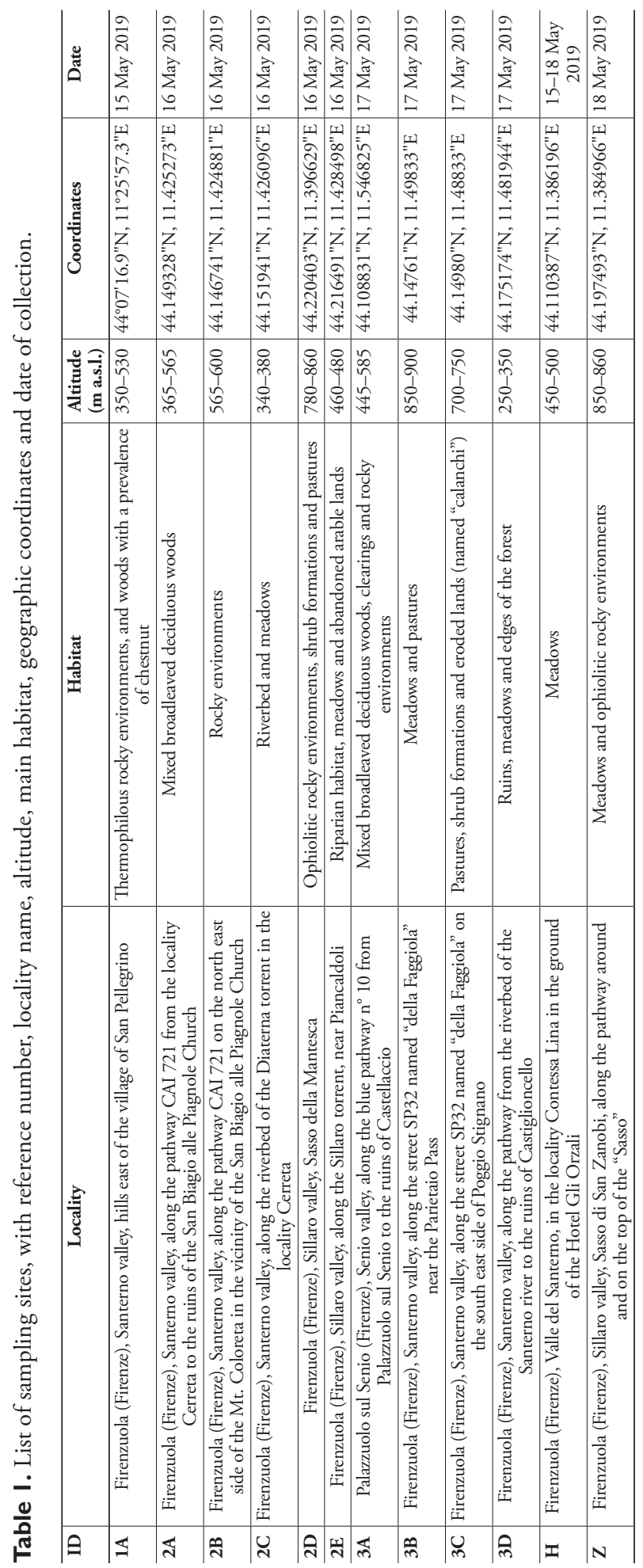


The sites were preliminarily investigated on March $20^{\text {th }}-22^{\text {nd }}$ and May $1^{\text {st }} 2019$ by the organisers, then sampled during the period May $15^{\text {th }}-18^{\text {th }} 2019$ by all participants. A comparative revision of critical collections and of unidentified specimens collected during the field work was carried out at the University of Pisa on February $5^{\text {th }}-7^{\text {th }} 2020$.

The nomenclature of taxa follows the updated checklists of the vascular flora native (Bartolucci et al. 2018) and alien (Galasso et al. 2018) to Italy and subsequent updates summarised in the Portal to the Flora of Italy (2020+; see also Martellos et al. 2020), except for native hybrids, not considered in the above-mentioned checklists. In the floristic list (Suppl. material 1, Part 3), the systematic order of the families follows Bartolucci et al. (2018) and Galasso et al. (2018). Within each family, taxa are ordered alphabetically. For each taxon, after the accepted scientific name, the following information is reported: endemic, cryptogenic and alien status, sampling locality, herbarium in which the collection is conserved (Suppl. material 1, Part 2). Abbreviations or symbols used in the floristic list are: E Italian endemic (according to Peruzzi et al. 2014, 2015; Bartolucci et al. 2018; Portal to the Flora of Italy 2020+); A Alien taxon and its status in Toscana: CAS (casual), NAT (naturalized), INV (invasive)]; C Cryptogenic taxon (doubtfully native taxon, whose origin of occurrence in Italy is unknown); $\mathrm{N}$ New record for the flora of Toscana.

\section{Results}

During the field investigations a total of 2,860 specimens were collected, belonging to 492 species and subspecies, 254 genera, and 77 families (Suppl. material 1, Part 3), including two native (Glechoma xpannonica Borbás and Salix apennina A.K.Skvortsov $\times$ S. caprea L.) and two alien (Vitis $\times$ instabilis Ardenghi, Galasso, Banfi \& Lastrucci and $V . \times$ koberi Ardenghi, Galasso, Banfi \& Lastrucci) hybrids.

Bromopsis caprina (A.Kern. ex Hack.) Banfi \& N.G.Passal., Ophrys appennina Romolini \& Soca, O. classica Devillers-Tersch. \& Devillers, Polygala flavescens DC. subsp. Alavescens, and Pulmonaria vallarsae A.Kern. subsp. apennina (Cristof. \& Puppi) L.Cecchi \& Selvi were the only five Italian endemics found in the study area.

A total of 28 alien taxa were detected of which 5 are casual, 16 naturalized and 7 invasive aliens (Ailanthus altissima (Mill.) Swingle, Artemisia verlotiorum Lamotte, Robinia pseudoacacia L., Senecio inaequidens DC., Veronica persica Poir., Vitis ×instabilis Ardenghi, Galasso, Banfi \& Lastrucci, and V. ×koberi Ardenghi, Galasso, Banfi \& Lastrucci).

Besides Bromopsis caprina, eight taxa (six native and two alien) are new for the regional flora of Toscana: Campanula portenschlagiana Schult. (casual alien), Crepis albida Vill. subsp. albida, Hypochaeris laevigata (L.) Ces., Pass. \& Gibelli, Potentilla neglecta Baumg., P. pusilla Host (Fig. 2), Pyrus nivalis Jacq., Rumex cristatus DC. (regional casual alien), and Taraxacum limosicola Kirschner \& Štěpánek. 


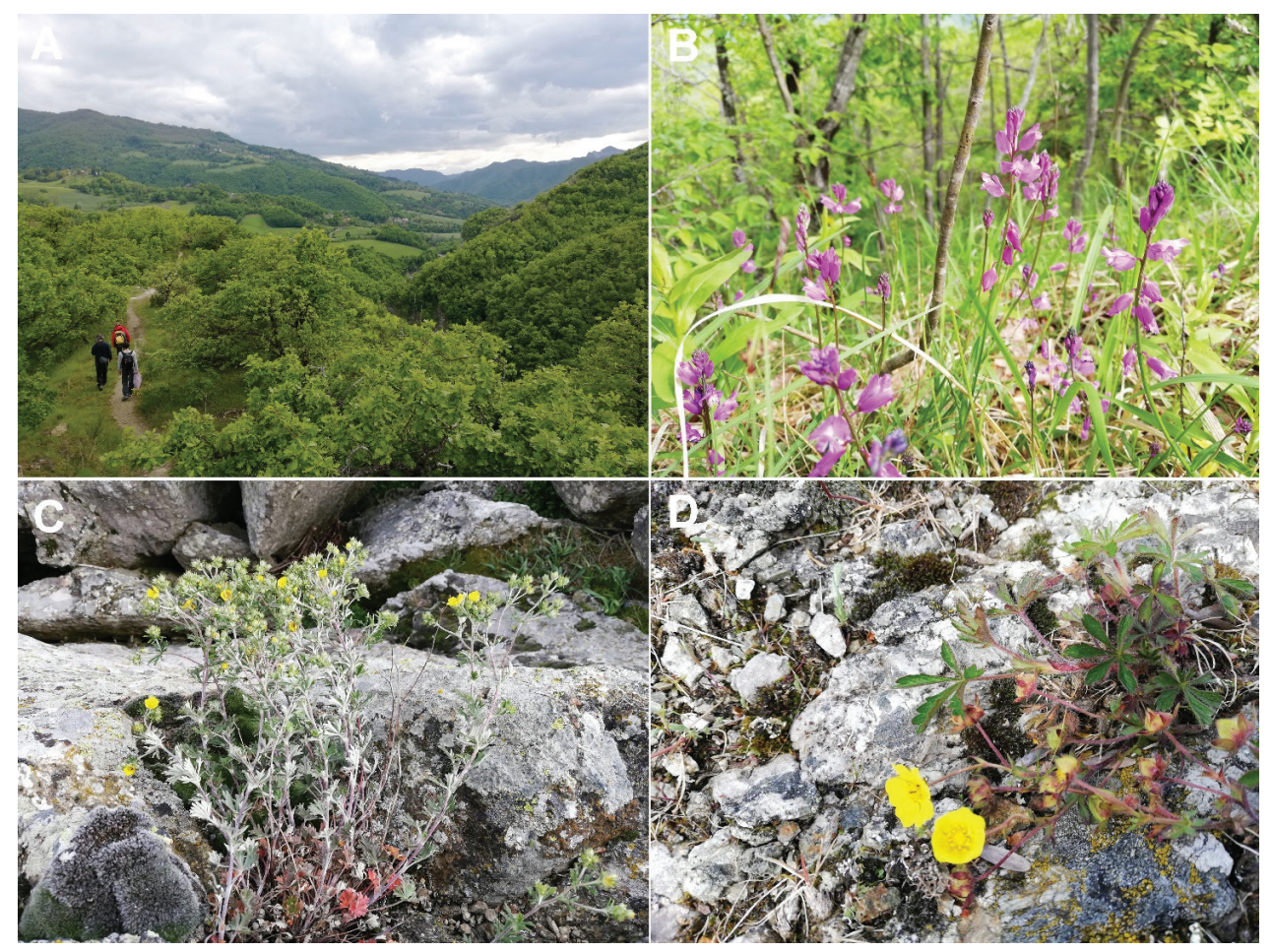

Figure 2. A view from the site 3D in Castiglioncello (Firenzuola, Firenze) (A); Polygala nicaeensis subsp. mediterranea from site 2A (B); Potentilla neglecta $(\mathbf{C})$ and P. pusilla $(\mathbf{D})$ from site $2 \mathrm{D}$, both new records for the flora of Toscana. For details on the sample sites, see Table 1. All photographs by L. Peruzzi.

\section{Discussion}

Among the 492 species and subspecies identified in this work, five are Italian endemics that occur in many other Italian regions, and are included in the Red List of the Italian endemic flora (Orsenigo et al. 2018, 2020) as LC ("Least Concern") with the exception of Polygala flavescens subsp. flavescens, which is reported as DD ("Data Deficient"). Among them, Bromopsis caprina was so far reported only for Lazio, Abruzzo, Campania, Basilicata, and Calabria (Bartolucci et al. 2018). This species was found only in a thermophilous rocky environment at the site $1 \mathrm{~A}$.

Concerning the native flora, besides B. caprina, six taxa are new for Toscana (Bartolucci et al. 2018). Crepis albida Vill. subsp. albida, found in the site 1A, reaches in this region its eastern distribution limit, occurring in France, Germany and in Italy only in Piemonte and Liguria (Greuter 2006+; Bartolucci et al. 2018). Potentilla neglecta occurs in Italy in Veneto, Trentino-Alto Adige, Abruzzo, and Lazio (Bartolucci et al. 2018, 2019). It was found in the site 2D, growing on ophiolitic rocks. In the same locality, we also collected Potentilla pusilla, growing in a pasture with ophiolitic outcrops. This species reaches in Toscana its southern distribution limit, occurring in Italy from Valle d'Aosta to Emilia-Romagna (Bartolucci et al. 2018). Pyrus nivalis 
was considered as native to Italy by Kurtto (2009), whereas Bartolucci et al. (2018) consider it as cryptogenic in Puglia and non-native in Trentino-Alto Adige. Only few individuals were found in the Santerno Valley (site 3B). Finally, still in site 2D we also collected Taraxacum limosicola and Hypochaeris laevigata. The former species belongs to Taraxacum sect. Palustria (H.Lindb.) Dahlst. (Kirschner and Stepánek 1998) and was so far reported only for Emilia-Romagna in Italy, from an area actually close this new locality (Peruzzi and Carlesi 2011). Hypochaeris laevigata reaches in Toscana its northern distribution limit, occurring in Sicily, Sardinia, Calabria, Basilicata, and Puglia (doubtful in Campania, Bartolucci et al. 2018). Among native non-endemic flora, Bellevalia romana (L.) Sweet, Colchicum lusitanum Brot., Crepis albida Vill. subsp. albida, Ophrys bertolonii Moretti subsp. bertolonii and Orchis provincialis Balb. ex Lam. $\&$ DC. are included in the Red List of the Italian flora (Rossi et al. 2013; Orsenigo et al. 2020) as LC.

Concerning Glechoma xpannonica, the occurrence of putatively hybrid populations between Glechoma hederacea L. and G. hirsuta Waldst. \& Kit. in central and northern Italy was already reported by Fiori and Beguinot (1903, under the name Glechoma hirsuta var. heterophylla (Opiz ex Rchb.) Bég.) and by Zangheri (1976, under the name Glechoma heterophylla Opiz). Also, Pignatti (1982) and Pignatti et al. (2018), reported the common occurrences of (unnamed) hybrids where the two parental species co-occur.

Among native species, the following 21 taxa are reported for the first time for the province of Florence (Peruzzi and Bedini 2020+, Roma-Marzio et al. 2016): Arabis planisiliqua (Pers.) Rchb., Asplenium ceterach L. subsp. bivalens (D.E.Mey.) Greuter \& Burdet, Bromopsis stenophylla (Link) Lazzeri, Campanula sibirica L. subsp. sibirica, Carex liparocarpos Gaudin subsp. liparocarpos, Cerastium brachypetalum Desp. ex Pers. subsp. roeseri (Boiss. \& Heldr.) Nyman, Coronilla vaginalis Lam., Crepis taraxacifolia Thuill., Galinsoga parviflora Cav., Helianthemum croceum (Desf.) Pers., Hornungia petraea (L.) Rchb. subsp. petraea, Lamium hybridum Vill., Luzula sylvatica (Huds.) Gaudin subsp. sieberi (Tausch) K.Richt., Orchis mascula (L.) L. subsp. speciosa (Mutel) Hegi, Orobanche alba Stephan ex Willd., Poa angustifolia L., Rosa squarrosa (A.Rau) Boreau, Saxifraga exarata Vill. subsp. pseudoexarata (Braun-Blanq.) D.A.Webb, Silene nemoralis Waldst. \& Kit., Trinia glauca (L.) Dumort. subsp. glauca, and Ziziphora granatensis (Boiss. \& Reut.) Melnikov subsp. granatensis. In addition, the occurrence of Rosa pulverulenta M.Bieb. in the site $2 \mathrm{D}$, represents the first recent finding for Toscana outside Apuan Alps (Peruzzi and Bedini 2020+).

Twenty-eight out of the 492 identified taxa (5\%) are non-native. Two of them are new for the flora of Toscana (Galasso et al. 2018): Campanula portenschlagiana and Rumex cristatus.

Campanula portenschlagiana is native to south-eastern Europe, and it was reported for the first time as alien in Italy for Lombardia (Banfi and Galasso 2010), and later reported as casual for Trentino-Alto Adige, Veneto, Emilia-Romagna, Umbria, and Abruzzo (Galasso et al. 2018). This species grows on an urban wall in the village of Piancaldoli, in the Sillaro valley (site 2E). Rumex cristatus is native to Balkans, and it was reported as cryptogenic in Sicily, but as invasive or naturalized alien in several other 
Italian regions (Galasso 2008; Galasso et al. 2018). We found only few plants colonizing the edge of a route in the village of San Pellegrino, in the Santerno valley (site 1A).

Among alien species, further four taxa (Allium shoenoprasum L. subsp. schoenoprasum locally alien, Alnus cordata (Loisel.) Duby, Avena sterilis L. subsp. ludoviciana (Durieu) Gillet \& Magne, and Bromopsis inermis (Leyss.) Holub subsp. inermis), are reported for the first time for the province of Florence (Peruzzi and Bedini 2020+, Roma-Marzio et al. 2016).

\section{Acknowledgements}

We are grateful to E. Banfi (Milano), G. Domina (Palermo) and G. Gottschlich (Tübingen) for the identification of some critical samples of Bromopsis Fourr., Hieracium L. and Pilosella Hill, and Orobanche L., respectively. The staff of Botanical Garden and Museum of Pisa is gratefully acknowledged for the logistic support during the revision of critical specimens.

\section{References}

Banfi E, Galasso G (2010) La flora esotica lombarda. Museo di Storia Naturale di Milano, Milano. [+ CD-Rom]

Baroni E (1897-1908) Supplemento generale al Prodromo della Flora Toscana di T. Caruel. Società Botanica Italiana, Firenze.

Bartolucci F, Cancellieri L, Conti F, Banfi E, Bouvet D, Celestini M, Ciaschetti G, Di Pietro R, Falcinelli F, Fascetti S, Galasso G, Lattanzi E, Masin RR, Pennesi R, Rosati L, Stinca A, Tilia A, Forte TGW, Scoppola A (2019) Contribution to the floristic knowledge of Velino and Aterno valleys (Lazio-Abruzzo, central Italy). Italian Botanist 7: 93-100. https://doi. org/10.3897/italianbotanist.7.34697

Bartolucci F, Peruzzi L, Galasso G, Albano A, Alessandrini A, Ardenghi NMG, Astuti G, Bacchetta G, Ballelli S, Banfi E, Barberis G, Bernardo L, Bouvet D, Bovio M, Cecchi L, Di Pietro R, Domina G, Fascetti S, Fenu G, Festi F, Foggi B, Gallo L, Gottschlich G, Gubellini L, Iamonico D, Iberite M, Jiménez-Mejías P, Lattanzi E, Marchetti D, Martinetto E, Masin RR, Medagli P, Passalacqua NG, Peccenini S, Pennesi R, Pierini B, Poldini L, Prosser F, Raimondo FM, Roma Marzio F, Rosati L, Santangelo A, Scoppola A, Scortegagna S, Selvaggi A, Selvi F, Soldano A, Stinca A, Wagensommer RP, Wilhalm T, Conti F (2018) An updated checklist of the vascular flora native to Italy. Plant Biosystems 152(2): 179-303. https://doi.org/10.1080/11263504.2017.1419996

Bedini G, Pierini B, Roma-Marzio F, Caparelli KF, Bonari G, Dolci D, Gestri G, D’Antraccoli M, Peruzzi L (2016) Wikiplantbase \#Toscana: breaking the dormancy of floristic data. Plant Biosyst 150(3): 601-610. https://doi.org/10.1080/11263504.2015.1057266

Caruel T (1860-1864) Prodromo della Flora Toscana. Ed. Felice Le Monnier, Firenze. https:// doi.org/10.5962/bhl.title.9990 
D’Antraccoli M, Pierini B, Roma-Marzio F, Gestri G, Caparelli KF, Bonari G, De Gaetano F, Dolci D, Consagra A, Calcara B, Pacifico B, Giannotti A, Cataldi G, Carta A, Bedini G, Peruzzi L (2018) Un lustro di Wikiplantbase \#Toscana: storia, traguardi e prospettive future. Codice Armonico 2018: 170-178.

De Dominicis V, Angiolini C, Gabellini A (2010a) Le serie di vegetazione della regione Toscana. In: Blasi C (Ed) La vegetazione d'Italia. Palombi \& Partner S.r.l., Roma, 205-230.

De Dominicis V, Angiolini C, Gabellini A (2010b) Carta delle serie di vegetazione della regione Toscana. In: Blasi C (Ed) La vegetazione d'Italia, Carta delle Serie di Vegetazione, scala 1:500.000. Palombi \& Partner S.r.l., Roma.

Fiori A, Béguinot A (1903) Flora analitica d'Italia, Vol. 3(1). Tipografia del Seminario, Padova, $1-272$.

Galasso G (2008) Due specie di Rumex L. (Polygonaceae) recentemente comparse in Italia settentrionale: R. cristatus DC. e R. kerneri Borbás. In: Galasso G, Chiozzi G, Azuma M, Banfi E (Eds) Le specie alloctone in Italia: censimenti, invasività e piani di azione. Memorie della Società Italiana di Scienze Naturali e Museo Civico di Storia Naturale di Milano 36(1): 60.

Galasso G, Conti F, Peruzzi L, Ardenghi NMG, Banfi E, Celesti-Grapow L, Albano A, Alessandrini A, Bacchetta G, Ballelli S, Bandini Mazzanti M, Barberis G, Bernardo L, Blasi C, Bouvet D, Bovio M, Cecchi L, Del Guacchio E, Domina G, Fascetti S, Gallo L, Gubellini L, Guiggi A, Iamonico D, Iberite M, Jiménez-Mejías P, Lattanzi E, Marchetti D, Martinetto E, Masin RR, Medagli P, Passalacqua NG, Peccenini S, Pennesi R, Pierini B, Podda L, Poldini L, Prosser F, Raimondo FM, Roma Marzio F, Rosati L, Santangelo A, Scoppola A, Scortegagna S, Selvaggi A, Selvi F, Soldano A, Stinca A, Wagensommer RP, Wilhalm T, Bartolucci F (2018) An updated checklist of the vascular flora alien to Italy. Plant Biosystems 152(3): 556-592. https://doi.org/10.1080/11263504.2018.1441197

Greuter W (2006+) Compositae (pro parte majore). In: Greuter W, Raab-Straube E von (Eds) Compositae. Euro+Med Plantbase - the information resource for Euro-Mediterranean plant diversity. https://doi.org/10.3372/wi.36.36206 [accessed 20 October 2020]

Kirschner J, Stepánek J (1998) A monograph of Taraxacum sect. Palustria. Institute of Botany, Academy of Sciences of the Czech Republic, Prühonice.

Kurtto A (2009+) Rosaceae (pro parte majore). In: Euro+Med PlantBase - the information resource for Euro-Mediterranean plant diversity. http://ww2.bgbm.org/EuroPlusMed/ [accessed 31 July 2020]

Martellos S, Bartolucci F, Conti F, Galasso G, Moro A, Pennesi R, Peruzzi L, Pittao E, Nimis PL (2020) FlorItaly - the portal to the Flora of Italy. PhytoKeys 156: 55-71. https://doi. org/10.3897/phytokeys.156.54023

Orsenigo S, Fenu G, Gargano D, Montagnani C, Abeli T, Alessandrini A, Bacchetta G, Bartolucci F, Carta A, Castello M, Cogoni D, Conti F, Domina G, Foggi B, Gennai M, Gigante D, Iberite M, Peruzzi L, Pinna MS, Prosser F, Santangelo A, Selvaggi A, Stinca A, Villani M, Wagensommer RP, Tartaglini N, Duprè E, Blasi C, Rossi G (2020) Red list of threatened vascular plant species in Italy. Plant Biosystems. https://doi.org/10.1080/11263504.2020.1739165

Orsenigo S, Montagnani C, Fenu G, Gargano D, Peruzzi L, Abeli T, Alessandrini A, Bacchetta G, Bartolucci F, Bovio M, Brullo C, Brullo S, Carta A, Castello M, Cogoni D, Conti F, Domina G, Foggi B, Gennai M, Gigante D, Iberite M, Lasen C, Magrini S, Perrino EV, 
Prosser F, Santangelo A, Selvaggi A, Stinca A, Vagge I, Villani MC, Wagensommer RP, Wilhalm T, Tartaglini N, Duprè E, Blasi C, Rossi G (2018) Red Listing plants under full national responsibility: extinction risks and threats in the vascular flora endemic to Italy. Biological Conservation 224: 213-222. https://doi.org/10.1016/j.biocon.2018.05.030

Peruzzi L, Bedini G [Eds] (2020+) Wikiplantbase \#Toscana v2.1 http://bot.biologia.unipi.it/ wpb/toscana/index.html [accessed 15.10.2020]

Peruzzi L, Carlesi V (2011) Notula: 1809. In: Barberis G, Nepi C, Peccenini S, Peruzzi L (Eds) Notulae alla checklist della flora vascolare italiana 11 (1751-1822). Informatore Botanico Italiano 43(1): 140.

Peruzzi L, Conti F, Bartolucci F (2014) An inventory of vascular plants endemic to Italy. Phytotaxa 168: 1-75. https://doi.org/10.11646/phytotaxa.168.1.1

Peruzzi L, Domina G, Bartolucci F, Galasso G, Peccenini S, Raimondo FM, Albano A, Alessandrini A, Banfi E, Barberis G, Bernardo L, Bovio M, Brullo S, Brundu G, Brunu A, Camarda I, Conti F, Croce A, Iamonico D, Iberite M, Iiriti G, Longo D, Manca A, Marsili S, Medagli P, Pistarino A, Salmeri C, Santangelo A, Scassellati E, Selvi F, Soldano A, Stinca A, Vacca G, Villani MC, Wagensommer RP, Passalacqua NG (2015) An inventory of the names of vascular plants endemic to Italy, their loci classici and types. Phytotaxa 196(1): 1-217. https://doi.org/10.11646/phytotaxa.196.1.1

Peruzzi L, Viciani D, Bedini G [Eds] (2010) Contributi per una flora vascolare di Toscana. I (1-85). Atti della Società Toscana di Scienze Naturali, serie B 116 (2009): 33-94.

Pesaresi S, Biondi E, Casavecchia S (2017) Bioclimates of Italy. Journal of Maps 13: 955-960. https://doi.org/10.1080/17445647.2017.1413017

Pignatti S (1982) Flora d'Italia, Vol. 3. Edagricole, Bologna.

Pignatti S, Guarino R, La Rosa M (2018) Flora d'Italia. Ed. 2, Vol. 3. Edagricole, New Business Media, Milano.

Portal to the Flora of Italy (2020+) Portale della Flora d'Italia/Portal to the Flora of Italy. 2020.1. http://dryades.units.it/floritaly/ [accessed 15.10.2020]

Regione Toscana (2019) GEOscopio. http://www502.regione.toscana.it/geoscopio/cartoteca. html [accessed 09.07.2020]

Rivas-Martínez S, Penas A, Díaz TE (2004) Bioclimatic map of Europe, thermoclimatic belts. University of León, Cartographic Service, León.

Roma-Marzio F, Bedini G, Müller J, Peruzzi L (2016) A critical checklist of the woody flora of Tuscany (Italy). Phytotaxa 287(1): 1-134. https://doi.org/10.11646/phytotaxa.287.1.1

Rossi G, Montagnani C, Gargano D, Peruzzi L, Abeli T, Ravera S, Cogoni A, Fenu G, Magrini S, Gennai M, Foggi B, Wagensommer RP, Venturella G, Blasi C, Raimondo FM, Orsenigo S (2013) Lista Rossa della Flora Italiana. 1. Policy Species e altre specie minacciate. Comitato Italiano IUCN e Ministero dell'Ambiente e della Tutela del Territorio e del Mare, Roma, 58 pp.

Scoppola A, Blasi C (Eds) (2005) Stato delle conoscenze sulla flora vascolare d'Italia. Palombi Editori, Roma, 253 pp.

Stinca A, Chianese G, D’Auria G, Fascetti S., Ravo M, Romano VA, Salerno G, Astuti G, Bartolucci F, Bernardo L, Bonari G, Bouvet D, Cancellieri L, Carli E, Caruso G, Catalano I, Cennamo GD, Ciaschetti G, Conti F, Di Pietro R, Fortini P, Gangale C, Lapenna MR, 
Lattanzi E, Marcucci R, Peccenini S, Pennesi R, Perrino EV, Peruzzi L, Roma-Marzio F, Scoppola A, Tilia A, Villani M, Rosati L (2019) Contribution to the floristic knowledge of eastern Irpinia and Vulture-Melfese area (Campania and Basilicata, southern Italy). Italian Botanist 8: 1-16. https://doi.org/10.3897/italianbotanist.8.37818

Viciani D, Baroni S, Nardi E (2008) Contribution to the knowledge of the vascular flora of Monte Beni and Sasso di Castro, two ultramafic mountains in Upper Mugello (Northern Tuscany). Webbia 63(2): 187-214. https://doi.org/10.1080/00837792.2008.10670842

Viciani D, Bucci A, Dell'Olmo L (2012) La vegetazione del sito di importanza comunitaria e regionale «Sasso di Castro e Monte Beni» (Alto Mugello, Toscana Settentrionale ): aspetti fisionomico-floristici (con carta in scala 1:10.000). Atti della Società Toscana di Scienze Naturali, Memorie, serie B 118 (2011): 47-56.

Viciani D, Lastrucci L, Bucci A (2011) Distribuzione di Hippophaë fluviatilis in Toscana e caratterizzazione fitosociologica delle cenosi riparie in cui risulta dominante. Fitosociologia 48(1): 77-90.

Zangheri P (1966) Romagna Fitogeografica (5). Flora e vegetazione del medio e alto Appennino Romagnolo. Webbia 21(1): 1-450. https://doi.org/10.1080/00837792.1966.10669838

Zangheri P (1976) Flora Italica, Vol. 1. Cedam, Padova, 1157 pp.

\section{Supplementary material I}

\section{Supplementary data}

Authors: Francesco Roma-Marzio, Marco D’Antraccoli, Daniele Angeloni, Fabrizio Bartolucci, Liliana Bernardo, Laura Cancellieri, Giuseppe Caruso, Fabio Conti, David Dolci, Giovanni Gestri, Leonardo Gubellini, Nicole Hofmann, Valentina L.A. Laface, Edda Lattanzi, Paolo Lavezzo, Giovanni Maiorca, Giulia Montepaone, Carmelo M. Musarella, Domenico Noto, Enrico V. Perrino, Elisa Proietti, Rizzieri R. Masin, Anna Scoppola, Adriano Stinca, Manuel Tiburtini, Agnese Tilia, Lorenzo Peruzzi

Data type: species data

Explanation note: 1. Participants to the field trip of the working group for Floristics, Systematics and Evolution of the Italian Botanical Society (May 15 ${ }^{\text {th }}-18^{\text {th }} 2019$ ). 2. Public and private herbaria in which the collected exsiccata are kept. 3. Inventory of the taxa collected during the field trip held in May 2019 along the High Valley of Sillaro, Santerno, and Senio (Toscana). 4. Pictures of selected species and landscapes shot during the field trip held in May 2019 along the High Valleys of Sillaro, Santerno, and Senio (Toscana).

Copyright notice: This dataset is made available under the Open Database License (http://opendatacommons.org/licenses/odbl/1.0/). The Open Database License $(\mathrm{ODbL})$ is a license agreement intended to allow users to freely share, modify, and use this Dataset while maintaining this same freedom for others, provided that the original source and author(s) are credited.

Link: https://doi.org/10.3897/italianbotanist.10.60118.suppl1 